\title{
Use of Arduino Microcontroller and Proteus Software in Physics Lesson in Review of Mathematics Ability and Critical Thinking Skills
}

\author{
Matsun ${ }^{1 *}$, Boisandi ${ }^{1}$, Ira Nofita Sari ${ }^{1}$, Soka Hadiati ${ }^{1}$, Sy. Lukman Hakim ${ }^{1}$ \\ ${ }^{1}$ Physics education, IKIP PGRI Pontianak, Pontianak, Indonesia.
}

DOI: $10.29303 /$ jppipa.v7iSpecialIssue.916

\section{Article Info}

Received: August 25th, 2021

Revised: October 30th, 2021

Accepted: November $5^{\text {th }}, 2021$

\begin{abstract}
This study aims to determine the effect and interaction of the use of learning media, mathematical abilities, and critical thinking skills on student achievement. The design of this research is experimental. Data were analyzed using a three-way ANOVA analysis of variance. The results showed: 1) there was an effect of cognitive and affective learning achievement of students who were given learning using Arduino microcontroller and Proteus software, but there was no effect on psychomotor learning achievement; 2) there is an effect of cognitive learning achievement of students who have high and low mathematical abilities, but there is no effect on affective and psychomotor learning achievement; 3 ) there is no effect on cognitive and affective learning achievement of students who have high and low critical thinking skills, but there is an effect on psychomotor learning achievement; 4) there is no interaction between the inquiry model using Arduino microcontroller and Proteus software with mathematical ability on students' cognitive, affective and psychomotor learning achievement; 5) there is no interaction between the inquiry model using Arduino microcontroller and Proteus software with critical thinking skills on student cognitive and psychomotor learning achievement, but there is an interaction on student affective learning achievement; 6) there is no interaction between mathematical ability and critical thinking skills on student achievement; 7) there is no interaction between the inquiry model using Arduino microcontroller and Proteus software, mathematical ability, thinking skills on student achievement.
\end{abstract}

Keywords: Arduino microcontroller, proteus software, mathematics ability, critical thinking skills.

Citation: $\quad$ Matsun, M., Boisandi, B., Sari, I. N., Hadiati, S., \& Hakim, S. L. (2021). Use of Arduino Microcontroller and Proteus Software in Physics Lesson in Review of Mathematics Ability and Critical Thinking Skills. Jurnal Penelitian Pendidikan IPA, 7(SpecialIssue), 20-27. https://doi.org/10.29303/jppipa.v7iSpecialIssue.916

\section{Introduction}

Physics lessons in college are a process to deliver students to the learning objectives to be achieved. The process of learning physics is the creation of situations and conditions that can trigger interactions between students and their learning objects. Learning physics is the result of experience, not just memorizing formulas. Learning physics as an experience by students means that physics is a vehicle for understanding physics concepts that require students to work with real media through experimental activities so that they gain knowledge (Waluyo et al., 2021). Physics learning in universities is directed to compare the approximate results with the theory through experiments based on the scientific method. Through learning, physics is expected to be a vehicle for students to learn the material in everyday life. The lecturer only acts as a facilitator who directs students to find the right concept. But in reality, the physics learning process that occurs is not following the functions and objectives of physics learning. Learning carried out in the classroom is mostly done using conventional methods (lectures), in delivering material the lecturer still dominates the 
class, students are not given the opportunity and freedom to develop their physical abilities so that students do not understand the concepts obtained (Maryuningsih and Manfaat 2019).

In the situation that happened in the physics education study program of IKIP PGRI Pontianak, direct observations showed that the learning process of Physics was still centered on the lecturer. Lecturers still have not applied appropriate learning models and media only centered on conventional learning models. This can be seen during the learning process in class. The lecturer begins learning by informing the material being studied then explaining and giving questions. The student activities at that time were only taking notes, listening, and working on questions, there was a lack of discussion in the learning process, only students occasionally asked and answered the questions given. So that the learning process feels boring and students look inactive and less motivated to be able to understand the material that has been given (Sukisna and Suparwoto 2020).

The assessment given to students who study through conventional methods (lectures, questions and answers, and assignments), shows $58 \%$ of students who have low learning achievements in digital electronics subjects. Based on the analysis of the questions given in the test, in general, the questions are made to test students' cognitive abilities which include aspects of understanding and applying concepts. This shows that students' understanding of concepts is still lacking and has not met the target. The low understanding of students is suspected to have something to do with the learning process that is applied still not using appropriate and innovative learning models and influenced by the background of previous students. So that it affects the low learning achievement of students (Hikmah et al., 2017).

The process of supporting learning that is no less important is the media. Media is a tool in learning and teaching. In the learning process, the media is needed by students as a tool so that students can easily understand the material being conveyed (Triatmaja and Khairudin, 2018). Teachers use the media for the learning process in the classroom so that the objectives of classroom learning are achieved.

Choosing learning media that makes it easier for students to understand the subject matter is the main task of the teacher. Determination of learning media is chosen according to the characteristics of the material and students in supporting the improvement of the teaching and learning process (Fuada et al., 2018). The media used must meet the criteria as media that support learning activities, so it is hoped that teachers must be able to determine and operate their learning media and create new media. Criteria that need to be considered in choosing media or laboratories include compatibility with the characteristics of the material, and teaching methods (Latifah et al., 2019).

Media that can be used in learning include using the Arduino microcontroller. Arduino is a microcontroller, which is a micro-sized computer in one IC chip (integrated circuit) consisting of a processor, memory, and programmable interface (Santosa, 2015). The Arduino board consists of readyto-use microcontroller hardware/modules and IDE software used for programming (Santosa, 2015). Arduino is a flexible programmable hardware base. Arduino-based projects require programming skills or knowledge of electronics theory. Arduino is an electronic device controller that has many benefits. Freitas et al (2018), Kubínová and légr (2015), Pereira (2016), have developed an Arduino device as a means of measuring physical quantities. Some of these studies show that the use of Arduino has succeeded in increasing students' thinking skills and reactivity in learning. In this study, Arduino will be used as a learning medium to instill student character.

In addition to using the Arduino microcontroller, the learning process also uses Proteus software. Where the use of Proteus software can develop students' science process skills. Digital electronics learning with Proteus software creates interaction between students and the Proteus program. Students can modify and manipulate parameters to produce certain consequences shown by the Proteus program. Proteus software can develop student process skills, namely skills to manipulate, test, explore, predict, formulate questions, build hypotheses, collect data and observe, analyze and give meaning to physical phenomena that occur (Waluyo et al. 2021). Using Proteus software, students can see changes that occur in a natural phenomenon that may be difficult to see or even have a dangerous risk if done with ordinary observations. Especially during the COVID-19 pandemic, virtual laboratories are very useful in the learning process.

Mathematical abilities and critical thinking skills are internal factors of students needed for learning to use Arduino microcontrollers and Proteus software, this is because in learning using Arduino microcontrollers and Proteus software students are expected to to to find their concepts directly through observation (Stahre Wästberg et al. 2019). Mathematical ability is very necessary for learning to use Arduino microcontroller and Proteus software because the mathematical ability is a basic ability that must be understood by students. So, in principle, students who have a good understanding of mathematical concepts will easily understand digital electronics concepts, thus understanding the level of digital electronics concepts 
has an impact on solving physics problems both in the form of physical content and questions that require mathematical calculations. Think critically according to Klentien and Wannasawade (2016) is a cognitive activity related to the use of reason, which means using mental processes, such as paying attention, categorizing, selecting, and decide. Higher thinking patterns are formed based on critical thinking. So in learning using Arduino microcontrollers and Proteus software, students' critical thinking skills are very necessary, because in learning using Arduino and virtual microcontrollers, students use their thinking skills a lot (Lestari and Supahar 2020).

\section{Method}

The population in this study were students of physics education study program IIP PGRI Pontianak for the academic year 2020/2021 which consisted of 2 classes with a total of 50 students. The sampling technique in this study used the Cluster Random Sampling technique. The research design used is experimental research that seeks to determine the effect of one variable on other variables. This research is experimental with research data design presented in a $2 \times 2 \times 2$ factorial design with analysis of variance (ANOVA) technique.

The instruments were used in the form of tests, questionnaires, and observation sheets. The instrument is in the form of a test to measure cognitive achievement, mathematical ability, and critical thinking skills. The test form instrument uses multiple-choice tests. The questionnaire was used to measure effective achievement, while the observation sheet was used to measure affective and psychomotor achievement at the time of the study.

\section{Result and Discussion}

The research data were tested using three-way ANOVA using the SPSS 18 program with the results as shown in Table 1.

Table 1. ANOVA Test Results of Cognitive, Affective, and Psychomotor Learning Achievements.

\begin{tabular}{lllll}
\hline No & Test & $\begin{array}{l}\text { Sig. } \\
\text { Cognitive }\end{array}$ & $\begin{array}{l}\text { Sig. } \\
\text { Affective }\end{array}$ & $\begin{array}{l}\text { Sig. } \\
\text { Psychomotor }\end{array}$ \\
\hline 1. & Hypothesis 1 & 0.001 & 0.041 & 0.810 \\
2. & Hypothesis 2 & 0.021 & 0.710 & 0.510 \\
3. & Hypothesis 3 & 0.310 & 0.610 & 0.000 \\
4. & Hypothesis 4 & 0.710 & 0.510 & 0.510 \\
5. & Hypothesis 5 & 0.031 & 0.410 & 0.041 \\
6. & Hypothesis 6 & 0.151 & 0.310 & 0.871 \\
7. & Hypothesis 7 & 0.650 & 0.710 & 0.310 \\
\hline
\end{tabular}

From the results of ANOVA analysis, if sig. > 0.05; then Ho is accepted while if sig. < 0.05; then Ho is rejected. From Table 1 can be discussed hypotheses for cognitive, affective, and psychomotor learning achievement data.

\section{The effect of learning using Arduino microcontroller and Proteus software on students' cognitive, affective, and psychomotor learning achievements.}

The results of the hypothesis test are shown in table 1. It shows that there is an influence on the cognitive and affective learning achievements of students who are given learning using the Arduino microcontroller and Proteus software. The psychomotor aspect does not influence the psychomotor achievement of students who are taught using a guided inquiry model using an Arduino microcontroller and Proteus software.

The average value of the cognitive aspect in the class that was given learning with the Arduino microcontroller was 60.70 , while the average value of the class that was taught using the Proteus software was 75.95. These data indicate that learning physics using Proteus software is better in improving students' cognitive learning achievement than classes using Arduino microcontrollers. This is in line with research conducted by (Rizal et al., 2018). The conclusion from the results of the study, it is known that students who are taught using Proteus software provide better achievements for students. Simulation plays a major role in learning, not only providing realistic models, but students can also interact to gain real-world experience. Proteus software is a safe environment where students can repeat the process without risk to know concepts and theories more easily.

Learning using Proteus software to understand Digital Electronics material theoretically has several advantages compared to learning using an Arduino microcontroller, this is following research conducted by (Waluyo et al. 2021). Virtual laboratories can be used practically, cheaply, and easily. Students can repeat experiments easily both on campus and at home, and animations and simulations make students more motivated in learning, and the price of Proteus software is cheaper than real laboratory equipment (Arduino microcontrollers). Students get carried away with the fun atmosphere in repeating the experiment so that much of the remaining time is used for discussion with the teacher.

There is a significant influence on the results of cognitive learning achievement from statistical tests this is because there are several factors that affect the results of the study. The results of the observation of the first factor, namely the influence of the learning process, the class that uses Proteus software, the 
majority of students play an active role in building the knowledge gained from the observed simulations, thus making learning on Digital Electronics material clearer and concrete, the second factor, students using Arduino microcontrollers the process of assimilation, accommodation, and equilibration cannot run optimally, this is due to the length of practicum activities so that it has an impact on the limited time for teachers to convey the concepts of the material being taught. Students are less than optimal in accepting material concepts because they only see and do practicum without being accompanied by a more detailed explanation from the teacher.

The average value of affective learning achievement in the class that was given learning with the Arduino microcontroller was 90.01 while the average value of the class that was given learning with the virtual laboratory was 97.02. These data indicate that digital electronics learning using Proteus software is better in improving students' affective learning achievement than classes using Arduino microcontrollers. The influence of affective learning achievement is due to interaction with lecturers in learning using a virtual laboratory that is more effective than the Arduino microcontroller. This is in line with research conducted (Klentien and Wannasawade 2016) From the results of the study it can be concluded that the Proteus software has a positive effect on student achievement and attitudes when compared to using Arduino microcontroller media. When viewed from the affective learning achievement observation sheet, which includes: willingness to accept lessons, pay attention to teacher explanations, desire to ask questions, willingness to study further subject matter, willingness to apply lesson results, careful in observing, honest in data collection, and work well together. The use of Proteus software will affect affective learning achievement, which is dominated by internal student factors, which are described by various activities and students' self-preparation to face the material to be delivered at home or outside class hours. For example, for students who repeat lessons using Proteus software, deepening material through virtual media that they already have will be easier than the Arduino microcontroller. This is in line with research conducted by (Tüysüz 2010) that the use of virtual laboratories can be used both in the classroom and outside the classroom.

There is no influence on psychomotor learning achievement because Arduino and virtual microcontrollers train students' psychomotor skills. Arduino and virtual microcontrollers both train students to conduct experiments. The effect of Arduino and virtual microcontrollers is only on the media used, namely on the Arduino microcontroller the tools and materials used are really real, while on the proteus software the tools and materials are in the form of a computer program. Thus, the Arduino microcontroller and Proteus software train psychomotor skills for students.

\section{The influence of cognitive, affective, and psychomotor learning achievement of students who have high and low mathematical abilities.}

The results of the hypothesis test in Table 1 show that there is an influence on the cognitive learning achievement of students who have high and low mathematical abilities, while in the affective and psychomotor aspects there is no influence on the learning achievements of students who have high and low mathematical abilities.

The average value of high mathematical ability in the cognitive aspect is 70.03 while the average value of low mathematical ability is 60.32. Based on students who have high mathematical abilities, the average cognitive value is greater than students who have low mathematical abilities, so students who have high mathematical abilities have a greater influence on cognitive learning achievement. This is because the Digital Electronics material is of high complexity and contains quite a lot of mathematical concepts, so a fairly high mathematical ability is needed, thus students who have high mathematical abilities will more easily and quickly understand Digital Electronics material and apply it to problems physics compared to students who have the low mathematical ability. This is in line with research conducted (González et al. 2019) that in physics, mathematics plays a major role. In addition to its ability to solve physics problems from simple to more complex, mathematics is very helpful in one's reasoning in exploring the intricacies of physics which require a quite high reasoning. Understanding the level of physics concepts has an impact on solving physics problems both in the form of physical concerns and physics problems that require mathematical calculations. Students who have high mathematical ability cognitive learning achievement will be high and students who have the low mathematical ability have low cognitive learning achievement.

Mathematical ability is an internal factor for students. It turns out that students who have high mathematical abilities have average affective and psychomotor scores which are not much different from the average affective and psychomotor scores of students who have low mathematical abilities. Mathematical ability does not affect affective and psychomotor learning achievement, because in affective learning achievement only attitude is assessed, not the ability to complete mathematical operations. Likewise with psychomotor learning achievement, 
because the media used to conduct experiments are Arduino and virtual microcontrollers, there is no effect of activeness in conducting experiments between students who have high and low mathematical abilities.

The influence of cognitive, affective, and psychomotor learning achievement of students who have high and low critical thinking skills.

The results of hypothesis testing are in Table 1. It shows that there is no effect of cognitive and affective learning achievement on students who have high and low critical thinking skills. The psychomotor aspect affects the psychomotor learning achievement of students who have high and low critical thinking skills.

Critical thinking skills are an attempt to apply rational, higher thinking activities, which include analyzing, synthesizing, recognizing problems and solving, concluding, and evaluating. Critical thinking is an important aspect that must be possessed by students both in learning and in social life. Critical thinking skills are closely related to one's ability to be openminded in dealing with various events or events (Klentien and Wannasawade 2016). In Digital Electronics material, something that is very important in understanding and applying concepts is the student's ability to analyze an event or event based on logic or reasoning, not based on open-mindedness in dealing with something by taking into account various reasons, both reasons from oneself and others from other people. So in this study, it turns out that critical thinking skills do not have a significant effect on cognitive learning achievement. Likewise with student affective learning achievement, because filling out effective questionnaires does not require critical thinking skills, only a simple level of thinking following the attitudes and morals that students face when receiving lessons.

In the psychomotor aspect, the average value of high critical thinking skills is 78.08 while the average value of low critical thinking skills is 66.78. Critical thinking proposed by (Lee, Sohod, and Ab Rahman 2019) i.e. critical thinking is a process that leads to the ultimate goal in the form of a reasonable conclusion or decision about what to believe and what action to take. However, critical thinking is done not only to seek answers but to question answers. Facts, or existing information. Thus, the best alternative or solution can be found. Someone who has high critical thinking skills will try to solve the problems faced in various ways and choose which way is the most appropriate to obtain a solution This can be seen from the results of psychomotor learning achievement of students with high critical thinking skills whose scores are better than students with low critical thinking skills. This is in line with Bruner's learning theory which assumes that knowledge acquisition is an interactive process.

Interaction between Arduino microcontroller media and Proteus software with mathematical ability on student learning achievement.

The results of hypothesis testing are in Table 1. It shows that the interaction between Arduino and virtual microcontroller media with mathematical ability does not have a significant effect on student's cognitive, affective, and psychomotor learning achievements. Learning with a guided inquiry model using Arduino microcontroller and Proteus software is part of cognitive learning theory (Shuaibu, 2014) states that learning is more successful if it is adjusted to the stage of cognitive development of students. Thus, teachers can provide appropriate treatment for their students, for example designing and implementing the learning process, providing teaching aids, and so on according to the stage of development of thinking skills possessed by each student. Students are allowed to make discoveries with physical objects, which are supported by interactions with peers and assisted by questions by the lecturer. Lecturers provide stimulation to students to want to interact with the environment actively, seek and find various things from the environment. Students build concepts from the results of their discoveries, in this study through media using Arduino and virtual microcontrollers, based on the results of cognitive, affective, and psychomotor hypothesis testing, that the level of mathematical ability and learning media have the same effect on students' cognitive, affective and psychomotor learning achievements.

\section{Interaction between Arduino microcontroller media and Proteus software with critical thinking skills on student achievement.}

The results of the hypothesis test are in Table 1, it shows the interaction between Arduino microcontroller media and Proteus software with critical thinking skills has a significant influence on students' cognitive and psychomotor learning achievements, while in the affective aspect, the interaction between Arduino microcontrollers media and Proteus software with critical thinking skills does not provide positive results significant influence on student affective learning achievement.

Digital Electronics Learning using Arduino microcontroller and Proteus software is learning that emphasizes the acquisition of material concepts through investigation. The concept was discovered by students through the investigation with the lecturer as a facilitator. To find concepts, students must be able to criticize, find the most appropriate problems from experiments using Arduino microcontrollers and 
Proteus software (Abdjul, Ntobuo, and Payu 2019). This of course requires critical thinking skills. Students who have critical thinking skills will easily find and solve problems. The use of Arduino microcontrollers and Proteus software on students who have high critical thinking skills get higher cognitive and psychomotor achievements than students who have low critical thinking skills. This is in line with research conducted by (Lee et al. 2019), which states that the learning process that emphasizes the development of critical thinking skills will significantly improve learning achievement. Students who have high critical thinking skills will get better learning achievement (Maryuningsih, Manfaat 2019).

Students who have low critical thinking skills can take digital electronics lessons when taught with an Arduino microcontroller. Arduino microcontroller gives a clear picture of the characteristics of digital electronics. This can be seen when students do a practicum, students look enthusiastic and happy in doing their practicum. Students who have low critical thinking skills experience many difficulties in operating, understanding the information provided by the Proteus software (Hermansyah et al. 2019). This can be seen in the results of the ANOVA further test that there is an interaction in the group of students who have low critical thinking skills if they are given learning using an Arduino microcontroller compared to students who have low critical thinking skills if they are given learning using Proteus software, it has a significant effect on cognitive and learning achievement psychomotor. Students who are given Proteus software and have high critical thinking skills get the highest cognitive achievement, while the lowest cognitive achievement is obtained by students who are given Arduino microcontroller media and have high critical thinking skills. For psychomotor learning achievement, students who are given Proteus software and have high critical thinking skills get the highest psychomotor achievement (Prahastuti et al. 2019). While the lowest psychomotor achievement was obtained in students who were given virtual laboratory media and had low critical thinking skills (Hikmah et al. 2017).

\section{Interaction between mathematical ability and critical thinking skills.}

The results of hypothesis testing in Table 1 show that the interaction between mathematical ability and critical thinking skills does not have a significant effect on students' cognitive, affective, and psychomotor learning achievement. Based on the results of the analysis of students who have high and low mathematical abilities, students who have high and low critical thinking skills get almost the same cognitive, affective, and psychomotor learning achievements (Syahminan 2020).

There is no interaction between mathematical ability and critical thinking skills on cognitive, affective, and psychomotor learning achievement because students who have high mathematical abilities and critical thinking skills in the learning process are more active, more initiative and have high self-confidence, while students who have the ability to Mathematical skills and low critical thinking skills tend to be passive, afraid or shy and more often ask their friends to be able to understand a concept.

Interaction between Arduino and virtual microcontroller media with mathematical ability and critical thinking skills on cognitive, affective, and psychomotor learning achievement.

The results of the hypothesis test in Table 1 show the test decision, the null hypothesis is accepted in the cognitive, affective, and psychomotor aspects. This means that the interaction between Arduino microcontroller media and Proteus software, mathematical abilities, and critical thinking skills does not have a significant effect on students' cognitive, affective and psychomotor learning achievements.

Students with high mathematical abilities and critical thinking skills have better thinking skills so they can find and solve problems in understanding concepts. Students with high mathematical abilities play an important role in solving problems related to mathematics. Likewise, students with high critical thinking skills play an important role in learning that involves study groups, especially in group discussion activities because they can contribute their thoughts to their groupmates (Firdaus et al. 2020).

Based on the description above, it can be understood that learning using the Arduino microcontroller and Proteus software on students with mathematical abilities and high critical thinking skills produces a better average learning achievement than students with low mathematical abilities and critical thinking skills. Learning using Arduino microcontrollers and Proteus software on students with mathematical abilities and critical thinking skills does not interact with cognitive, affective, and psychomotor learning achievements because learning techniques with Arduino microcontrollers and Proteus software used in the learning process will not have an optimal effect if they are not supported by abilities mathematical and critical thinking skills are sufficient (Syahminan 2020). The use of Arduino microcontrollers and Proteus software in physics learning can be seen in the pictures below. 


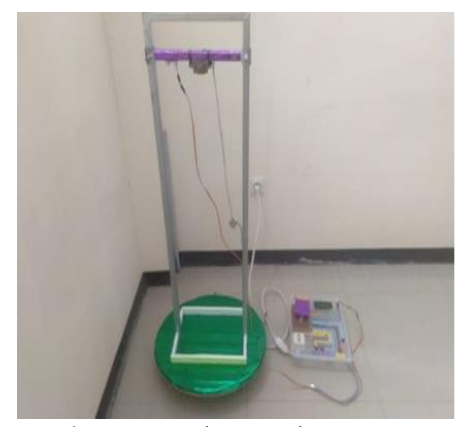

Figure 1. Physics learning using Arduino microcontroller

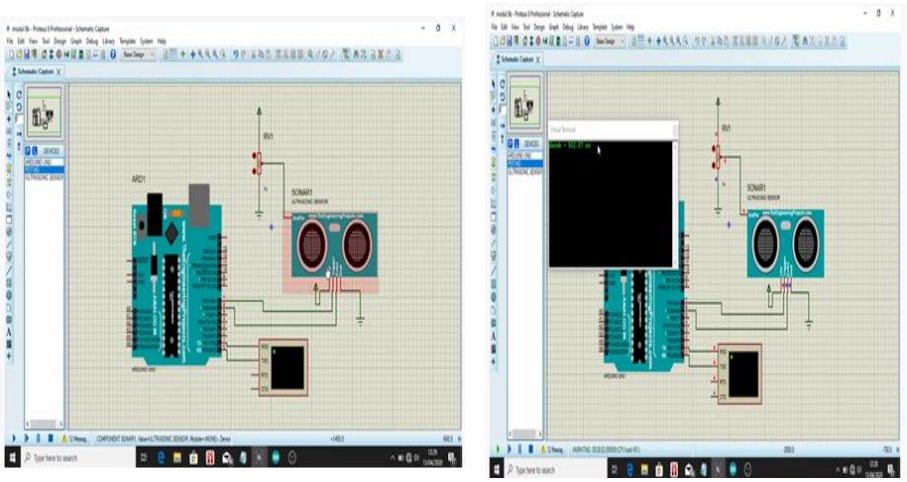

Figure 2. Physics learning using Proteus software

\section{Conclusion}

The results of this study can be concluded that there is an effect of cognitive and affective learning achievement of students who are given learning using Arduino microcontroller and Proteus software, but there is no effect on psychomotor learning achievement. There is an effect of cognitive learning achievement of students who have high and low mathematical abilities, but there is no effect on affective and psychomotor learning achievement. There is no effect on cognitive and affective learning achievement of students who have high and low critical thinking skills, but there is an effect on psychomotor learning achievement. There is no interaction between the inquiry model using Arduino microcontroller and Proteus software with mathematical ability on students' cognitive, affective and psychomotor learning achievement. There is no interaction between the inquiry model using Arduino microcontroller and Proteus software with critical thinking skills on student cognitive and psychomotor learning achievement, but there is an interaction on student affective learning achievement. There is no interaction between mathematical ability and critical thinking skills on student achievement. There is no interaction between the inquiry model using Arduino microcontroller and Proteus software, mathematical ability, thinking skills on student achievement.

\section{Acknowledgments}

The researchers thank the National Research and Innovation Agency Deputy for Research and Development Strengthening (BRIN) who has funded this activity through the Insinas 2021 grant, as well as the IKIP PGRI Pontianak institution which provided support and facilities in this research.

\section{References}

Abdjul, T., Ntobuo, N., \& Payu, C. (2019). Development of Virtual Laboratory-Based of Learning to Improve Physics Learning Outcomes of High School Students. Jurnal Pendidikan Fisika Indonesia, 15(2), 97-106. doi:https://doi.org/10.15294/jpfi.v15i2.12367

Artanto, D., Budi Cahyono, E. A., Siswoyo, A., \& Effendi, S. M. (2020). The effectiveness of learning in vocational education in mechatronics through making a simple simulation program. Journal of Physics: Conference Series, 1516, 12034. https://doi.org/10.1088/17426596/1516/1/012034

Firdaus, Fatiatun, Jumini, S., Trisnowati, E., \& Dahnuss, D. (2020). Proteus as a virtual simulation to improve readiness and process skills in laboratory experiment. Journal of Physics: Conference Series, 1517, 12074. https://doi.org/10.1088/17426596/1517/1/012074

Fuada, S., Elmunsyah, H., \& Suwasono. (2018). PengembanganTrainer Osilator Analog berbasis IC Op-Amp (Studi Kasus Penelitian R\&D di JTE FT UM). JUPITER (Jurnal Pendidikan Teknik Elektro), 3, 50-68. https://doi.org/10.25273/jupiter.v3i1.2388

González, J. D., Escobar, J. H., Beltrán, J. R., GarcíaGómez, L., \& La Hoz, J. De. (2019). Virtual laboratories of electromagnetism for education in engineering: A perception. Journal of Physics: Conference Series, 1391, 12157. https://doi.org/10.1088/17426596/1391/1/012157

Hermansyah, H., Gunawan, Harjono, A. \& Adawiyah. R. (2019). Guided Inquiry Model with Virtual Labs to Improve Students' Understanding on Heat Concept. Journal of Physics: Conference Series 1153(1). DOI: https://doi.org/10.1088/17426596/1153/1/012116

Hikmah, N., Saridewi, N., \& Agung. A. (2017). Penerapan Softwere proteus Untuk Meningkatkan Pemahaman Konsep Mahasiswa. EduChemia (Jurnal Kimia Dan Pendidikan) 2(2):186. doi: 
https://doi.org/10.30870/educhemia.v2i2.1608.

Kholis, N., Syariffuddien Zuhrie, M., \& Rahmadian, R. (2018). Innovation Online Teaching Module Plus Digital Engineering Kit with Proteus Software through Hybrid Learning Method to Improve Student Skills. IOP Conference Series: Materials Science and Engineering, 336, 12036. https://doi.org/10.1088/1757$\underline{899 x / 336 / 1 / 012036}$

Klentien, U., \& Wannasawade, W. (2016). Development of Blended Learning Model with Virtual Science Laboratory for Secondary Students. Procedia Social and Behavioral Sciences, 217, 706-711. https://doi.org/10.1016/j.sbspro.2016.02.126

Latifah, Z., Ikhsan, J., \& Sugiyarto, K. (2019). Effect of virtual chemistry laboratory toward cognitive learning achievement. Journal of Physics: Conference Series, 1156, 12034. https:// doi.org/10.1088/17426596/1156/1/012034

Lee, M. F., Mohd Sohod, S. N., \& Ab Rahman, \& A. (2018). Exploring the Mastery Level of Critical Thinking and Problem Solving Skill Among the Technical Undergraduate. Journal of Technical Education and Training, 11(3). Retrieved from https://publisher.uthm.edu.my/ojs/index.php/ ITET/article/view/3061

Lestari, D.P., \& Supahar. (2020). Students and Teachers' Necessity toward Virtual Laboratory as an Instructional Media of 21st Century Science Learning. Journal of Physics: Conference Series 1440(1). doi: https://doi.org/10.1088/1742$\underline{6596 / 1440 / 1 / 012091}$

Maryuningsih, Y.-, Manfaat, B., \& Riandi, R. (2019). Penerapan Laboratorium Virtual Elektroforesis Gel Sebagai Pengganti Praktikum Riil. Phenomenon : Jurnal Pendidikan MIPA, 9(1), 4864. https:// doi.org/10.21580/phen.2019.9.1.3320

Prahastuti, S., Hidayat, M., Hasianna, S. T., Widowati, W., Amalia, A., Yusepany, D. T., Rizal, R., \& Kusuma, H. S. W. (2019). Antioxidant potential ethanolic extract of Glycine max (1.) Merr. Var. Detam and daidzein. Journal of Physics: Conference Series, 1374, 12020. https://doi.org/10.1088/1742$\underline{6596 / 1374 / 1 / 012020}$

Rizal, A., Adam, R. I., \& Susilawati, S. (2018). Pengembangan Laboratorium Virtual Fisika Osilasi. Jurnal Online Informatika, 3(1), 55. https:// doi.org/10.15575/join.v3i1.140

Shuaibu, G. (2014). Cultural Practices and Mathematical Thinking Ability Among Hausa and Yoruba Secondary School Students in Kano and Oyo State, Nigeria. Journal of Technical Education and Training (JTET) 6(2):56-72. Retrieved from https://publisher.uthm.edu.my/ojs/index.php/ ITET/article/view/998

Stahre Wästberg, B., Eriksson, T., Karlsson, G., Sunnerstam, M., Axelsson, M., \& Billger, M. (2019). Design considerations for virtual laboratories: A comparative study of two virtual laboratories for learning about gas solubility and colour appearance. Education and Information Technologies, 24(3), 2059-2080. https://doi.org/10.1007/s10639-018-09857-0

Sukisna, \& Suparwoto. (2020). Development of Outdoor Learning To Improving Learning Outcomes Reviewed From Abstract Thinking Ability, Response To Guidelines and Science Process Skills for. Paedagoria: Jurnal Kajian, Penelitian Dan Pengembangan Kependidikan, 11(1), 44-52.

https://doi.org/10.31764/paedagoria.v11i1.1891

Syahminan. (2020). Pengembangan Pembelajaran Teknik Digital Dengan Media Perangkat Lunak Proteus Dan Emulator. Jurnal SPIRIT 12(2):41-45

Triatmaja, A.K., \& Khairudin, M. (2018). Study on Skill Improvement of Digital Electronics Using Virtual Laboratory with Mobile Virtual Reality. Journal of Physics: Conference Series 1140(1). doi: https://doi.org/10.1088/17426596/1140/1/012021

Tüysüz, C. (2010). The Effect of the Virtual Laboratory on Students' Achievement and Attitude in Chemistry. International Online Journal of Educational Sciences 2(1):37-53

Waluyo, B. D., Bintang, S., \& Januariyansah, S. (2021). The Effect of Using Proteus Software as A Virtual Laboratory on Student Learning Outcomes. Paedagoria: Jurnal Kajian, Penelitian Dan Pengembangan Kependidikan, 12(1), 140-145. Retrieved from: http://journal.ummat.ac.id/index.php/paedago $\underline{\mathrm{ria} / \text { article/view/4247 }}$ 